For numbered affiliations see end of article.

n.hopkinson@imperial.ac.uk Cite this as: BMJ 2021;374:n1839 http://dx.doi.org/10.1136/bmj.n1839 Published: 22 July 2021
GOVERNMENT AMBITION TO MAKE ENGLAND SMOKE-FREE BY 2030

\section{Open letter to the prime minister and secretary of state on the second anniversary of England's announcement that it would be smoke-free by 2030}

\author{
Nicholas S Hopkinson, ${ }^{1}$ Helen Stokes-Lampard, ${ }^{2}$ Jennifer Dixon, ${ }^{3}$ Maggie Rae, ${ }^{4}$ Linda Bauld, ${ }^{5}$ \\ Sarah Woolnough, ${ }^{6}$ Andrew Goddard, ${ }^{7}$ Jeanelle de Gruchy, ${ }^{8}$ Charmaine Griffiths, ${ }^{9}$ lan Walker, ${ }^{10}$ \\ Jon Bennett ${ }^{11}$
}

Two years ago today the government announced its ambition to make England smoke-free by $2030 .{ }^{12}$ This includes making smoked tobacco obsolete, with smokers quitting or moving to reduced risk products like e-cigarettes. Despite acknowledging that it would be "extremely challenging," there is still no sign to date of the "bold action" the government promised to deliver this crucial public health objective.

Although we are a world leader in tobacco control, the current rate of decline in smoking is insufficient to deliver the ambition. ${ }^{3}$ Indeed, since it was announced over 200000 children under 16 in England have started smoking, ${ }^{4}$ two thirds of whom will go on to become daily smokers. ${ }^{5}$

Half the difference in life expectancy between rich and poor people is the result of smoking, ${ }^{6}$ and the economic, as well as health, gains from a smoke-free country will benefit most those in disadvantaged groups and disadvantaged regions. ${ }^{7}$ Smoking is estimated to have killed more people last year than covid-19 and will do so for many years to come unless the government takes action. ${ }^{8}$ Tobacco is the public health epidemic hiding in plain sight. ${ }^{9}$

Delivering the smoke-free ambition would play a major role in achieving government manifesto commitments to increase healthy life expectancy by five years by 2035 , while reducing inequalities and levelling up the nation. The blueprint to achieve this is laid out in the All Party Parliamentary Group on Smoking and Health's recommendations for the forthcoming Tobacco Control Plan, which we all endorse.

The comprehensive and sustained strategy recommended in the report can deliver, if properly funded. But given the many competing priorities for the forthcoming comprehensive spending review, public health is unlikely to be prioritised. The alternative, which the government promised to consider when it announced its smoke-free ambition, is a US-style "polluter pays" levy on the tobacco manufacturers. ${ }^{1}$

The All Party Parliamentary Group's report sets out how a levy on manufacturers could raise $€ 700 \mathrm{~m}$ (€813m; \$96om) in year one alone, without the costs being passed on to smokers, now that we have left the European Union. This could pay for delivery of the Tobacco Control Plan and provide additional funding that public health desperately needs. ${ }^{7}$ In
2019 Imperial Tobacco made $£ 71$ for every £10o in sales $^{10}$-these are extreme profits, many times higher than those made by other consumer product manufacturers. ${ }^{11}$ The time has come to make tobacco manufacturers pay to end the epidemic that they and they alone have caused.

\begin{tabular}{l} 
AUTHOR AFFILIATIONS \\
\hline 1 Action on Smoking and Health \\
2 Academy of Medical Royal Colleges \\
3 \\
${ }^{3}$ The Health Foundation \\
4 Faculty of Public Health \\
5 University of Edinburgh \\
6 Asthma UK and British Lung Foundation \\
7 Royal College of Physicians \\
8 Association of Directors of Public Health \\
9 British Heart Foundation \\
${ }^{4}$ Cancer Research UK \\
${ }^{11}$ British Thoracic Society
\end{tabular}

Competing interests: HS-L is an employed professor at the University of Birmingham ( 0.5 whole time equivalent) and GP principal the Westgate Practice, an NHS General Medical Services GP surgery (part time). She is chair of the Academy of Medical Royal Colleges, chair of the National Academy for Social Prescribing, trustee of Macmillan Cancer, patron of Kendall and Wall charity (patient transport local to my surgery), member/fellow of several medical royal colleges and faculties, member of the BMA, and member of the Society for Academy Primary Care. JB is expert adviser for BMJ Best Practice and deputy medical director of RCP Invited Service Reviews. All other authors: none declared.

Department of Health and Social Care. Advancing our health: prevention in the 2020s-consultation document. 22 Jul 2019.

https://www.gov.uk/government/consultations/advancing-our-health-prevention-in-the-2020s/advancing-our-health-prevention-in-the-2020sconsultation-document

Mahase E. Prevention green paper lacks ambition, say critics. BMI 2019;366:14829. doi: 10.1136/bmj.l4829 pmid: 31337611

3 Cancer Research UK. Smoking prevalence projections for England, Scotland, Wales, and Northern Ireland, based on data to 2018-19. Feb 2020. https://www.cancerresearchuk.org/sites/default/files/cancer_research_uk_smoking_prevalence_projections_february_2020_final.pdf NHS Digital. Smoking, drinking and drug use in young people in England surveys 2016 and 2018. https://digital.nhs.uk/data-and-information/publications/statistical/smoking-drinking-and-drug-use-among-young-peoplein-england

5 Birge M, Duffy S, Miler JA, Hajek P. What proportion of people who try one cigarette become daily smokers? A meta-analysis of representative surveys. Nicotine Tob Res 2017. doi: 10.1093/ntr/nt×243 pmid: 29126298 
6 Jha P, Peto R, Zatonski W, Boreham J, Jarvis MJ, Lopez AD. Social inequalities in male mortality, and in male mortality from smoking: indirect estimation from national death rates in England and Wales, Poland, and North America. Lancet 2006;368:367-70.

doi: 10.1016/S0140-6736(06)68975-7 pmid: 16876664

7 All Party Parliamentary Group on Smoking and Health. Delivering a Smokefree 2030: The All Party Parliamentary Group on Smoking and Health recommendations for the Tobacco Control Plan 2021. 2021. https://ash.org.uk/wp-content/uploads/2021/06/APPGTCP2021.pdf

8 Royal College of Physicians. Smoking and health 2021: a coming of age for tobacco control?2021. https://www.rcplondon.ac.uk/projects/outputs/smoking-and-health-2021-coming-age-tobaccocontrol

9 Royal College of Physicians. Hiding in plain sight: treating tobacco dependency in the NHS. 2018. https://www.rcplondon.ac.uk/projects/outputs/hiding-plain-sight-treating-tobacco-dependencynhs

10 Imperial Tobacco Limited. Annual report and financial statements for the year ended 30 September 2019. 2020. https://www.imperialbrandsplc.com/content/dam/imperial-brands/corporate/investors/annual-report-and-accounts/2019/Annual\%20Report\%202019.pdf.downloadasset.pdf

11 Branston JR, Gilmore A. The extreme profitability of the UK tobacco market and the rationale for a new tobacco levy. 2015. https://researchportal.bath.ac.uk/en/publications/the-extreme-profitability-of-the-uk-tobacco-market-and-the-ration 